\title{
Limits to database protection: fair use and scientific research exemptions
}

Citation for published version (APA):

Kamperman Sanders, A. W. J. (2006). Limits to database protection: fair use and scientific research exemptions. Research Policy, 35, 854-874. https://doi.org/10.1016/j.respol.2006.04.007

Document status and date:

Published: 01/01/2006

DOI:

10.1016/j.respol.2006.04.007

Document Version:

Publisher's PDF, also known as Version of record

Document license:

Taverne

Please check the document version of this publication:

- A submitted manuscript is the version of the article upon submission and before peer-review. There can be important differences between the submitted version and the official published version of record.

People interested in the research are advised to contact the author for the final version of the publication, or visit the DOI to the publisher's website.

- The final author version and the galley proof are versions of the publication after peer review.

- The final published version features the final layout of the paper including the volume, issue and page numbers.

Link to publication

\footnotetext{
General rights rights.

- You may freely distribute the URL identifying the publication in the public portal. please follow below link for the End User Agreement:

www.umlib.nl/taverne-license

Take down policy

If you believe that this document breaches copyright please contact us at:

repository@maastrichtuniversity.nl

providing details and we will investigate your claim.
}

Copyright and moral rights for the publications made accessible in the public portal are retained by the authors and/or other copyright owners and it is a condition of accessing publications that users recognise and abide by the legal requirements associated with these

- Users may download and print one copy of any publication from the public portal for the purpose of private study or research.

- You may not further distribute the material or use it for any profit-making activity or commercial gain

If the publication is distributed under the terms of Article $25 \mathrm{fa}$ of the Dutch Copyright Act, indicated by the "Taverne" license above, 


\title{
Limits to database protection: Fair use and scientific research exemptions
}

\author{
Anselm Kamperman Sanders* \\ Maastricht University, Faculty of Law, P.O. Box 616, 6200MD Maastricht, The Netherlands
}

Available online 12 June 2006

\begin{abstract}
A trend running diametrically opposed to the expansion of Intellectual Property Rights (IPR) is the increasing awareness that dominant positions sustained by IPR may be mitigated through exemptions and statutory or compulsory licences. It is argued that there are compelling economic reasons to protect valuable assets that are prone to copying, but that there are equally compelling reasons to limit monopolistic claims and stimulate cross-licensing practices. Compulsory licensing may serve as a stimulus to the bargaining process with private parties and research institutions alike. Another important category of information is public sector information. Access to information has become a concern and the European Commission has followed up on its Green Paper on Public Sector Information in the Information Society, with a Directive implementing its vision on affordable access for all and exploitation potential. The right of access to information may be enforced through the European Convention on Human Rights. It not only guarantees the freedom of speech, it also recognises the freedom to receive information.
\end{abstract}

(C) 2006 Elsevier B.V. All rights reserved.

JEL classification: $\mathrm{H} 4 ; \mathrm{K} 39 ; \mathrm{O} 31 ; \mathrm{O} 34$

Keywords: Intellectual property rights; Copyright; Sui generis protection of databases; Economics of information goods; Open science

\section{Introduction}

In view of widespread counterfeiting and the TRIPs (Trade Related Aspects of Intellectual Property) infused desire to obtain international recognition from policymakers and investors alike, action has been taken to find solutions to piracy and market failure by stretching the boundaries of copyright and other Intellectual Property Rights (IPR). The expansion of the rationale for IPR is, however, a common trend. With new creative exploits in high technology and new methods of marketing intellectual property, statutes are seemingly continuously tinkered with in order to prevent piracy

\footnotetext{
* Tel.: +31 433883216; fax: +31 433258981.

E-mail address: a.kampermansanders@pr.unimaas.nl.
}

and market failure. A common trend is to combat market failure where it occurs by the introduction of sui generis legislation bearing the classic hallmarks of misappropriation theory. The clearest example of this expansion is the emergence of database rights, ${ }^{1}$ which in particular has prompted an increasing number of critics to voice concerns. They feel that creativity is under threat, simply because access to vital information or the exploitation thereof for further development or basic research is hampered by monopolistic claims. This paper explores the economic justifications for the law of unfair competition or misappropriation (Besen and Raskind, 1991). In order to grasp these economic considerations, the economics of the statutory 'property-rule' regimes of trademark,

\footnotetext{
${ }^{1}$ Directive 96/9/EC, 11 March 1996, No. L 77/20.
} 
patent, copyright and database protection are contrasted with the economics of protection of confidential information and other forms of 'liability-rules' that are employed to regulate competition. The effects of market dominance sustained by a property or a liability rule on competition are considered.

A trend running diametrically opposed to the expansion of IPR is the increasing awareness that dominant positions sustained by IPR may be mitigated through exemptions and statutory or compulsory licences. The TRIPS Agreement does indeed allow for compulsory or statutory licensing to take place, provided certain conditions are met. Not only does traditional IPR law often allow for fair use of research exemptions, it also recognises the link between the IPR and competition law system. Therefore attention is given to regulations, such as the Treaty of Rome, which forbid the abuse of a dominant position. It is argued that there are compelling economic reasons to protect valuable assets that are prone to copying, but that there are equally compelling reasons to limit monopolistic claims and stimulate cross-licensing practices. To this end the concept of compulsory licensing may serve as a stimulus to the bargaining process with private parties and research institutions alike.

Another important category of information is public sector information. Whereas early US database proposals contained a paragraph on government collections of information, ${ }^{2}$ the EC Database Directive does not. At the implementation stage in the Member States, however, access to information has become a concern. An exception for public sector information was, for example, introduced in The Netherlands. ${ }^{3}$ Furthermore, certain Member States begun to examine the effects of new technologies on the public service, especially on access to and exploitation of public sector information. ${ }^{4}$ The European Commission (EC) followed suit by publishing its Green Paper on Public Sector Information in the Information Society ${ }^{5}$, outlining its vision on

\footnotetext{
$2 \S 1204$ (a) of H.R.354. Two versions of Bill Number H.R.354 were before the 106th Congress: (i) Collections of Information Antipiracy Act (Introduced in the House) H.R.354.IH January 19, 1999; (ii) Collections of Information Antipiracy Act (Reported in the House) H.R.354.RH October 8, 1999.

3 Art. 8 (1) Databankenwet (Dutch Database Act) 8 July 1999, Stb. 1999, 303.

${ }^{4}$ In the UK, Freedom of Information White Paper; in The Netherlands, Towards the Accessibility of Government Information; and in France, Preparing France's Entry into the Information Society.

5 COM(98)585final, adopted on 20 January 1999, followed by Directive 2003/98/EC of the European Parliament and the Council of 17 November 2003 on the re-use of public sector information. Official Journal L345/90 of 31-12-2003.
}

affordable access for all, exploitation potential and fair competition.

A further development for such a right of access to information may be found in the domain of human rights. The European Court of Human Rights (ECtHR) ${ }^{6}$ was willing to strike out the application of the Swiss Unfair Competition Act $^{7}$ following publication of a scientific article stating that consumption of food prepared in microwave ovens was dangerous to human health, because of concerns over freedom of speech, as contained in Art. 10 of the European Convention on Human Rights (ECHR). The ECHR guarantees freedom of speech and also recognises the freedom to receive information. It may therefore be that the balancing of interests between the freedom to receive information versus the intellectual property rights of others, ${ }^{8}$ will prove to be an issue that the Strasbourg Court will no longer shy away from. A Panel Discussion on Intellectual Property and Human Rights ${ }^{9}$ suggests that WIPO is also developing an interest in the relationship between IP and human rights.

The guarantee of a free flow of information is therefore no longer an issue that is limited by the discussion on the scope of IP rights and the traditional exceptions thereto.

\section{The economic justification for intellectual property rights}

Free and unrestricted competition lies at the heart of the generally accepted western economic theory. Free play of market forces, or free competition between enterprises, is thought to be the best means to satisfy supply and demand and to maximise wealth in society as a whole. Central to this proposition is the axiom that market participants can compete on a level playing field, so that all competitors face the same market barriers, thus facilitating freedom of entry in the market. From this point of view legal interference in the market should be kept to a minimum. This does not mean, however, that the policy towards markets should

\footnotetext{
${ }^{6}$ Hertel v. Switzerland (59/1997/843/1049), 25 August 1998. For an assessment of the case and its implications see Sanders (1999).

${ }^{7}$ Federal Unfair Competition Act of 19 December 1986.

${ }^{8}$ Vide art. 10(2) ECHR, setting out the restrictions to the freedom of speech.

9 A Panel Discussion in commemoration of the 50th Anniversary of the Universal Declaration of Human Rights on intellectual property and human rights organised by the WIPO in collaboration with the Office of the United Nations High Commissioner for Human Rights, 9 November 1998. See also Drahos (1999).
} 
be one of laissez faire. There is a compelling argument for laissez faire in that interference in the market brings with it administrative costs that are incurred from the transfer the costs of competition from one market participant to the other. Market intervention should result therefore in a clear social benefit. In the competitive game, the process of spreading market information facilitates the shaping of the opinion of market participants with regard to profit making activities ${ }^{10}$ and is seen as socially beneficial. Government intervention to enhance this aspect of competition is generally accepted, even in classical economic theory. This adage has given rise to the premise in neo-classical theory that perfect knowledge induces a situation in which the spontaneous interaction between knowledge possessors leads to a state of equilibrium, the optimum distribution of resources in society. This means that disturbances in knowledge creation, leading to imperfect knowledge, need to be countered (Hayek, 1948, p. 530). Legal intervention should therefore be aimed at providing a level playing field of 'market information' in which perfect knowledge induces perfect competition. Laws on the protection of intellectual property and competition can be seen in this light. Entitlements are allocated to specific creators, to safeguard their information against expropriation, so that bargaining can facilitate an exchange and a market is created. With most intellectual and industrial creations, the establishment of a market for ideas is possible only if the value of the idea can be assessed in advance. This generally means revealing that idea to a potential buyer, who will then already have acquired the idea at no cost (Arrow, 1962, pp. 609-615). Government intervention through the creation of a property right facilitates the bargaining process and the creation of a market for copyright materials and the information contained therein. After the creation of the entitlement, the role of the State is finished, leaving the transfer of the entitlement to the market, where a voluntary bargain can be made between buyer and seller. This implies that the value of the entitlement is also determined by the market and not by the State. This means that the value determination and maximisation require the least State intervention (Calabresi and Melamed, 1972, pp. 1092, 1105). According to the Coase Theorem (Coase, 1960), even the allocations of initial entitlements by the State are unimportant, since they will be transferred to their high-

\footnotetext{
10 "Competition is essentially a process of the formation of opinion: by spreading information [i]t creates the views people have about what is best and cheapest" (Hayek, 1948, p. 106).
}

est value use through private bargaining, leaving the total output of the economy unaffected. One system of property rights is no more efficient than another in this view. This means, however, that the transaction costs of the (re)allocation of property rights and the rules governing the exchange determine the efficiency of one system over the other (Merges, 1994). In addition, the cost effectiveness of a protective regime depends on the social costs that are incurred when protection is afforded in error and when the likelihood of overprotection by the system is real.

The economic rationale for the patent system (see Kaufer, 1989; Heald, 1991, pp. 962-965), commonly described as a system of incentives and rewards, can, for example, more aptly be described as a monopoly that creates a barrier to entry, ${ }^{11}$ forcing a licensing practice to evolve. This serves two ends. First, the competitor faces a market barrier equivalent to that encountered by the first market entrant, that the competitor would not encounter as a 'free-rider', thus levelling the playing field and inducing him to be creative himself. Second, the creator produces a wider variety of works that the public may be willing to pay for, since creativity is stimulated. This gives the consumer more choice and facilitates the creation of new markets. Without the protective regime of the patent system, which excludes 'free-riders', a situation of asymmetric market failure could emerge. Market failure is a situation where creators are not rewarded for their creative efforts. This makes it economically more attractive to copy than to create, resulting in creators producing fewer works than the public would be willing to pay for. The aspect of asymmetry is the situation where one party, the creator, faces a market barrier and the other, a copyist, does not. ${ }^{12}$ If a combination of market failure and asymmetry occurs, a pattern emerges that holds true for all forms of intellectual property law.

Just like the patent system, which serves to stimulate disclosure of the invention and thus encourages further development, the copyright system ${ }^{13}$ should allow for utilisation of information, either by addition to the public domain or by rights acquisition on a licensing basis. Where new work relies on prior work and ideas, the new work should not benefit the copyright holder in monopoly rents in excess of the value the copyrighted

\footnotetext{
11 See Demsetz (1982, p. 47). "The problem of defining ownership is precisely that of creating properly scaled legal barriers to entry".

12 For a definition of asymmetric market failure and the role of intellectual property law in providing a remedy against the resulting loss in wealth, see Gordon (1992a).

${ }^{13}$ For a representation of classical patent and copyright protection and the varying level of creativity required, see Mackaay (1996).
} 
work has added to total welfare. ${ }^{14}$ The other situation would lead to wasteful competition (Besen and Raskind, 1991, p. 5) to gain those rights that dispel the value of the underlying work, which often consists of contributions by others that may already be in the public domain or have never been susceptible to copyright (WarrenBoulton et al., 1994). In addition, if there are many potential users of the work, which is especially true when works have become de facto industry standards, ${ }^{15}$ it may become too costly to negotiate individual licences for every use that is made of it. Disclosure of the information and the fair use doctrine in copyright law can redress the economic imbalance that this increase in transaction costs entails. ${ }^{16}$ The trademark system displays different characteristics (Cornish and Phillips, 1982; Economides, 1988; Landes and Posner, 1987a), in that it was not envisaged as a system of incentives and rewards, but as a regulation of marketing efforts. As an identifier of products and their sources, a trademark performs the role of a communicator, a messenger that spreads information about what is best, the level and consistency of quality, and what is cheapest. Protection of trademarks ensures that the consumer can make correct purchasing decisions, ${ }^{17}$ thus lowering the transaction costs. ${ }^{18}$ The confusion rationale is also expressed in the doctrine of passing off, where it also serves to prevent the consumer from incurring increased transaction costs, guaranteeing to the marketeer that his or her message is heard without interference.

Protection of trade secrets is again underpinned by the notion of incentives and rewards, but may be located in the realm of unfair competition law (Besen and Raskind,

\footnotetext{
14 See Landes and Posner (1989, pp. 347-353) where the economic rationale for not protecting ideas is given.

15 US v. Microsoft. The Findings of Fact of the District Court are reported at 84 F. Supp. 2d 9 (J.S. App. 46-246). The Conclusions of Law of the District Court are reported at 87 F. Supp. 2d 30 (J.S. App. 1-43). The Final Judgment of the District Court is reported at 97 F. Supp. 2d 59 (J.S. App. 253-279). The Order of the District Court certifying the case under the Expediting Act (J.S. App. 284-285) 20 June 2000. For further developments see http://www.usdoj.gov/atr/cases/ms_index.htm.

16 See Gordon (1982) as to the extent of the 'fair use' doctrine. See also Landes and Posner (1989, pp. 357-361).

17 The consumer is the "unnamed third party in every action for trademark infringement", since the interest of the consumer lies in the ability of the trademark to facilitate choice on the basis that a trademark guarantees uniformity of quality at a consistent level (Diamond, 1980, p. 529).

18 Akerlof (1970, p. 488) demonstrated that this also applies to the quality function of the trademark. In his work he succinctly describes the market breakdown that occurs when the consumer can no longer trust the quality message a mark conveys.
}

1991, pp. 23-24). As an item of sensitive information it may have commercial value and so may attract the interest of competitors. Here lies one of the major differences from the fixed costs associated with obtaining a patent, in that the value of the trade secret and the costs that have to be incurred in order to protect it are directly related to the willingness of another to try to steal it. The parties do not bargain themselves, neither are they able to, since one of the parties intends to keep the asset secret. A regime that protects trade secrets, therefore, veers towards a liability-rule-based system in which the transfer of an entitlement is protected and its value is determined by the State.

In the patent system, independent invention, reverse engineering and public disclosure do not detract from the proprietary right in the patent, ${ }^{19}$ but in the case of trade secrets they do. Someone who sets out to uncover and apply another's trade secret may bring about social gain by increasing competition, but he may equally reduce the incentive to invent by inducing asymmetric market failure (Friedman et al., 1991, pp. 69-70). Trade secrecy protection serves to reduce the social costs that comprise expenditures for protection of trade secrets on one hand, and the cost of "not investing resources designed to effect a transfer of wealth" (Landes and Posner, 1987a,b, Chapter 6) on the other. In balancing those costs associated with the upkeep of a protective regime and the costs associated with the absence of a market structure that facilitates bargaining and sale of information, trade secrecy protection is limited to tortuous interference with an entitlement that is not absolute in nature. An inventor relying on a trade secret cannot prevent the application of independent research and, if the resulting invention is patentable, he cannot even prevent a second market entrant from patenting the invention, forcing the original inventor out of the market. In the first instance all market entrants face the same market barriers. This places reverse engineering in a peculiar position. It is not a method of independent research and may be considered theft. Friedman and Landes (Friedman et al., 1991, p. 70) advance two reasons against liability for reverse engineering, namely the administrative cost associated with proof that independent research did not take place, and the public disclosure argument. The line between piracy and acceptable reverse engineering then lies in the presence of substantial investment and innovation. This means that reverse engineering does not create a monopolistic barrier to entry and the investment and innovation associated with it do not induce asymmetry in

\footnotetext{
${ }^{19}$ Provided that the entitlement is enforced by the state.
} 
the market since all market entrants face similar market barriers.

\section{Property rules and liability rules}

The differing rationales of patent and trade secrets or confidential information regimes may also be used to demonstrate the justification in an economic sense for each particular protective regime. The incentive and reward rationale can be found in both the patent and confidential information regimes, but it is modified by the property rule and liability rule dichotomy, which underlines the varying economic considerations that shape either regime. The work of Calabresi and Melamed (1972) demonstrates the economic considerations that are relevant to make a considered choice between the regimes.

The patent system is based on a property rule, where the State-sanctioned monopolistic entitlement enables the proprietor in advance to set a price for the use of his asset by others. From an economic point of view this system makes sense if transaction costs are low, there are few parties and the value of the asset is difficult to assess (Calabresi and Melamed, 1972; Merges, 1994, pp. 2664-2667). In view of a legal entitlement, legitimate use of the asset can be made only after bargaining with the owner of the property right.

A liability rule, on the other hand, does not rely on a bargaining process prior to the transfer of an intangible asset, but the situation is assessed ex post in order to determine the correct amount of compensation for appropriation. A liability rule is economically effective in those cases where there are many parties and high transaction costs which interfere with the bargaining process. ${ }^{20}$ The economic efficiency of the liability rule is further heightened if the value of the asset can be easily assessed by the arbiter who has to settle a dispute. In view of the valuation problems that courts face in liability and property rule systems alike, damages and restitution rates are often assessed on an equitable basis, resulting in the 'reasonable royalty'. The reasonable royalty should be set at a level that makes the copyist face the same market barrier as the creator, by remedying the market failure the creator suffers.

\footnotetext{
${ }^{20}$ High transaction costs induced by market failure lead to a situation in which a liability rule is more efficient. See Reichmann (1994) and also Merges (1994, p. 2668), who distinguishes another situation in which an exception to the property rule for intellectual property rights is efficient. Compulsory licence regimes defer the bargaining process and valuation of intellectual property away from party autonomy.
}

In the free market, the property rule appears to be the most liberal, since it minimises State intervention in the valuation of assets, leaving it to the market to maximise wealth by voluntary transaction. Despite the fact that a property rule is often the most cost effective, since it stimulates party autonomy as opposed to State intervention in the transaction process, the policing of the property rule may require so much State intervention that the system is less cost effective than in a liability-rule-based system. This is increasingly true in the information society, where assets develop the characteristics of public goods, due to the fact that information based assets are costly to develop, but vulnerable to rapid and widespread duplication (Reichmann, 1994, p. 2443). Furthermore, within the property rule system, barriers to entry are created, which may stifle competition. The absolute nature of property rights also does not take into account that some forms of 'infringement' may be economically desirable for society. Economic theory has come up with two tests to determine whether the act of appropriation of an asset in the face of a monopolistic claim is efficient. The first, the so called Kaldor-Hicks test (Kaldor, 1939; Hicks, 1939), is a test of whether the 'infringer' can pay off the inventor and still find parties who are willing to value the infringer's product more highly. If this is the case, the exercise of a monopoly to the detriment of another is not economically justifiable. Where protection of intangible assets is concerned, this means that an injunction preventing the appropriation of an asset is not a correct option. This test, however, does not take into account that benefits and costs are not independent of the distribution of wealth. If the asset is appropriated without compensation, wealth is redistributed, but this does not mean that the situation that then comes about is efficient. Efficiency may in fact dictate that the old monopolistic situation is restored, for example, because the original developer is better placed to benefit society in the light of incentiveand reward-based innovation considerations. To avoid this paradox one also has to test whether the monopolistic claimant can pay the potential 'infringer' to cease and desist from appropriation of the intangible that is the bone of contention. If the answer is negative, then exercising monopoly power is not economically efficient. This so called Scitovszky test (De Scitovszky, 1941) serves to remedy that asymmetry and can be taken in tandem with the Kaldor-Hicks test. If both tests are passed, appropriation of an intangible is efficient and monopoly power should not be exercised in order to obtain injunctive relief. In effect the tests serve to determine whether copying results in the creation of new products that society is willing to pay for, without destroying the market for the source product. 
When making a choice between a liability and a property rule, the desirability of the application of the Kaldor-Hicks and Scitovszky tests is also a consideration. The absolute nature of intellectual property rights does not leave room for the tests. However, statutory exceptions to the monopoly are the elements that can be tested for their effectiveness. It is equally clear that the elasticity of the liability-rule-based doctrine of misappropriation facilitates the assessment of fact on the basis of the Kaldor-Hicks and Scitovszky tests in a way that property rule systems cannot. This means that if a choice is made for a liability rule, and party autonomy in the assessment of the value of an asset by means of transfer bargaining is diverted to an arbiter, the efficiency of the transfer as such can be tested.

\section{Commodification of information and databases}

The discussion on the protection of databases encompasses both the distinction between property and liability rules, as well as concerns over abuse of dominance in the exercise of database rights of access to information that is needed for the creation of new works that society is willing to pay for, but that do not undermine the market for the source database. ${ }^{21}$ The data mining industry is growing in importance. In the electronic environment information is not just a means to do business, it is a business commodity in itself. Electronic commerce and the new economy are starting to have an increasing impact on public policy and human interaction. To an increasing extent value to the economy is represented by the accumulated knowledge present in the organisation (Stewart, 1997). Information, the currency of the new economy, has the capacity to generate exponentially growing new amounts of information. This requires organisations to adapt their processes, and forces legislators to provide a legal, social and cultural framework for the new economy. In the interest of providing privacy and security to the citizen and industry alike, governments are pressed to regulate data processing industries. ${ }^{22}$ Article 2(5) of the Berne Convention, as clarified by the WIPO Copyright Treaty (WCT) sets the scene for this next section. Article 5 of the WCT states: "Compilations of data or other material, in any form, which by reason of the selection or arrangement of their contents constitute intellectual cre-

\footnotetext{
${ }^{21}$ See Kaldor (1939), Hicks (1939) and De Scitovszky (1941) as well as the related discussion on the Kaldor-Hicks and Scitovszky tests above.

${ }^{22}$ See the contributions of Reback and Kelly to Wired, August 1997; see also Kelly (1998).
}

ations, are protected as such", and is the guiding principle in civil law jurisdictions for the subsistence of copyright law, requiring some level of originality as the threshold for protection. This demarcation was, however, not always so clear. Under English copyright law, for example, "skill, judgement and labour", "selection, judgement and experience", but also "labour, skill and capital" were sufficient, making it possible to protect white-listed telephone directories. The implementation of the EC Database Directive ${ }^{23}$ changed this situation, restricting the scope of UK copyright law for the future. To this date, however, databases created before 27 March 1996 may be subject to compilation copyright in the UK. ${ }^{24}$ Before we come to the EC Database Directive, it is important to reflect upon the pivotal year 1991, because it was then that the US Supreme Court in Feist v. Rural Telephone Services $^{25}$ set the threshold for copyright protection in a major common law system and drew a line between original and non-original works. ${ }^{26}$ This provided clarity for international copyright, but uncertainty for producers of databases, who felt exposed to misappropriation. The irony is also plain to see. The more exhaustive you are (the more labour, skill and capital you invest) in compiling a database, the smaller are your chances of demonstrating that there is a sufficient level of original selection or arrangement to warrant copyright protection. This combination explains why lawyers are being told by some that old rights need to be strengthened ${ }^{27}$ and new ones need to be created ${ }^{28}$ in order to combat market failure. Some even go so far as to assert that: "Intellectual property law cannot be patched, retrofitted, or expanded to contain digitised expression ... We will need to develop an entirely new set of methods as befits this entirely new set of circumstances" (Barlow, 1994, p. 85). Whereas I do not wish to challenge here that protec-

\footnotetext{
${ }^{23}$ Directive 96/9/EC of the European Parliament and of the Council of 11 March 1996 on the legal protection of databases, OJ L 77, 27 March 1996, p. 20. For a description of the Directive and other database protection initiatives see Reichmann and Samuelson (1997, p. 51), Gaster (1999) and Kübler (1999).

${ }^{24}$ The Copyright and Rights in Database Regulations 1997, SI 1997/3032 of 18 December 1997, entry into force 1 January 1998, S. 29(1).

${ }^{25}$ Feist Publications Inc. v. Rural Telephone Service Company Inc, 111 S Ct. 1282; 113 L Ed 2d 358; 20 IPR 129 (US Supreme Court, 1991).

${ }^{26}$ See in this respect also the Van Dale v. Romme, Dutch Supreme Court, 4 January 1991, NJ 1991, 608, in which protection was denied to a list of words in a dictionary.

27 WIPO Copyright Treaty and WIPO Performances and Phonograms Treaty of 20 December 1996.

${ }^{28}$ Directive 96/9/EC of 11 March 1996, no L 77/20, and S. 2291, 10 July 1998; see also Laddie (1996, p. 260).
} 
tion is necessary in order to promote innovation, ${ }^{29}$ use of information does not exclude or place any costs on others using the same information and, as such, information is a public good.

\section{Databases in the European union}

At the end of the day, however, database producers found a willing ear in their combat against market failure in the EC, which incorporated a new sui generis database right in a Directive and also initiated an, albeit failed, attempt to elevate this new right to the world stage. ${ }^{30}$ The resulting Draft WIPO Treaty on Databases ${ }^{31}$ was part of the Diplomatic Conference, ${ }^{32}$ which lead to the adoption of the WCT and the WIPO Performances and Phonograms Treaty only. Nevertheless, WIPO (WIPO doc. SCCR/7/5) still emphasises the need for adequate database protection also in developing countries, especially in view of the great potential for data generation in the area of traditional knowledge and the genomic industry (DNA sequence databases).

Article 1.1 of this Directive defines a "database' as "a collection of independent works, data or other materials arranged in a systematic or methodical way and individually accessible by electronic or other means". This definition is, however, not very limiting. Court decisions show that almost any amalgamation of data will fall within the definition. ${ }^{33}$

Protection under the Database Directive comprises copyright protection of databases which “. . . by reason of the selection or arrangement of their contents, constitute

\footnotetext{
${ }^{29}$ One only needs to look at critical appraisal of database protection to see that investment and reward theories legitimise the creation of incentives for innovation. See Reichmann and Samuelson (1997).

30 WIPO, Committee of Experts on a possible Protocol to the Berne Convention, Third Session, Geneva, 21 to 25 June 1993; Memorandum on the Questions Concerning a Possible Protocol to the Berne Convention, Part II, WIPO document ref. BCP/CE/III/2-II (12 March 1993).

${ }^{31}$ Basic Proposal for the Substantive Provisions of the Treaty on Intellectual Property in Respect of Databases to be considered by the Diplomatic Conference, prepared by the Chairman of the Committees of Experts on a Possible Protocol to the Berne Convention and on a Possible Instrument for the Protection of the Rights of Performers and Producers of Phonograms, WIPO document ref. CRNR/DC/6 (30 August 1996).

32 The Diplomatic Conference on Certain Copyright and Neighboring Rights Questions was held in Geneva from 2 to 20 December 1996. http://www.wipo.int/eng/diplconf/index.htm (accessed 25 March 2002).

${ }^{33}$ Hugenholtz (2001) available at http://www.ivir.nl/publications/ hugenholtz/fordham2001.pdf (accessed 11 April 2002), listing cases involving web pages and classified ads in a newspaper.
}

the author's own intellectual creation ...". ${ }^{34}$ This produces an equivalent effect to the decision in the Feist case in most European jurisdictions subject to the Directive. In order to fill the resulting gap, the Directive requires member states to introduce a new sui generis protection. Article 7 defines the object of protection as follows:

1. "Member States shall provide for a right for the maker of a database which shows that there has been qualitatively and/or quantitatively a substantial investment in either the obtaining, verification or presentation of the contents to prevent extraction and/or re-utilisation of the whole or of a substantial part, evaluated qualitatively and/or quantitatively, of the contents of that database.

2. For the purposes of this Chapter: (a) 'extraction' shall mean the permanent or temporary transfer of all or a substantial part of the contents of a database to another medium by any means or in any form; (b) 'reutilisation' shall mean any form of making available to the public all or a substantial part of the contents of a database by the distribution of copies, by renting, by on-line or other forms of transmission. The first sale of a copy of a database within the Community by the rightholder or with his consent shall exhaust the right to control resale of that copy within the Community; Public lending is not an act of extraction or re-utilisation."

Both for databases that do not pass the threshold for copyright protection and for databases that do, sui generis protection is available. This right is much stronger than copyright as it is primarily designed to provide the producer of a database with control over access to and use of a database. Copyright is infringed by reproduction of a material part of a work, which is judged quantitatively and qualitatively, so that the occasional entry into a database and the extraction of a small part of it, may well not infringe copyright in that database. Infringement of the sui generis right is defined as "extraction and/or re-utilisation of the whole or of a substantial part, evaluated qualitatively and/or quantitatively, of the contents of that database". At first sight, this might not appear much stronger than copyright, but, Article 7.5 states that:

"The repeated and systematic extraction and/or reutilisation of insubstantial parts of the contents of the database implying acts which conflict with normal exploitation of that database or which unreasonably prej-

\footnotetext{
${ }^{34}$ Article 3.1.
} 
udice the legitimate interests of the maker of the database shall not be permitted."

Although the initial term of database right is only 15 years from the 1st January following completion of the database, substantial changes, evaluated quantitatively and qualitatively, to the database including changes resulting from successive additions, deletions or alterations, which would result in the database being considered as having undergone substantial new investment, evaluated quantitatively and qualitatively, result in a renewal of the term of protection. The effect of this is that up-to-date and time-sensitive databases will enjoy perpetual database right.

\section{The effects of the Directive so far}

The EC Database Directive is still pretty much work in progress. The year 2002 should have seen a Commission evaluation of the Directive. ${ }^{35}$ Despite a limited circulation study on the implementation of the Directive undertaken by the Dutch law firm Nauta Dutilh, the first evaluation of the Directive was only published on 12 December 2005. ${ }^{36}$ The evaluation of the Directive makes painfully clear that the efficacy of the Directive in terms of its objective to stimulate database industries in the EU is not met.

Upon introduction of the Directive there was a sharp increase in the number of companies entering the database market in France, Germany and the UK. ${ }^{37}$ Whereas this provides credence to the idea that IPR protection fosters investment, this increase has since petered out. The production of databases in the European Union is still low in comparison to production in the United

\footnotetext{
35 Art. 16(3) EC Database Directive, Footnote 23: "Not later than at the end of the third year after the date referred to in paragraph 1 [1 January 1998], and every three years thereafter, the Commission shall submit to the European Parliament, the Council and the Economic and Social Committee a report on the application of this Directive, in which, inter alia on the basis of specific information supplied by the Member States, it shall examine in particular the application of the sui generis right, including Articles 8 and 9, and especially whether the application of this right has led to abuse of a dominant position or other interference with free competition which would justify appropriate measures being taken, in particular the establishment of non-voluntary licensing arrangements. Where necessary, it shall submit proposals for adjustment of this Directive in line with developments in the area of databases".

${ }^{36}$ The Implementation and Application of Directive 96/9/EC on the Legal Protection of Databases, Study-Contract ETD/2001/B53001/E/72; DG Internal Market and Services Working Paper, First evaluation of Directive 96/9/EC on the legal protection of databases (2005).

37 Maurer et al. (2001, p. 789).
}

States. At best the effect of the Database Directive on the production of new databases appears to be nil. Policy options stated in the evaluation therefore even include the withdrawal of the sui generis database right. Protection under the Directive has primarily been sought by companies generating so-called 'synthetic data', which are not collected, but made-up. It is also in this area that the scope of the sui generis database right gave rise to concern over stifling effects of the Directive. Unlike genuine information, for example in the area of genomics or nuclear physics, synthetic data are not available through independent research. Telephone directories, horseracing and other sporting events information and broadcast schedules cannot be duplicated through independent invention or creation. It is in this area where antitrust considerations over abuse of dominant positions in primary markets to control downstream markets are most prevalent.

In early database cases Dutch courts addressed this problem by refusing to extend protection to databases based on investments that the producer has made as a result of other, non-database-related, activities. Similarly in Sweden the Gotland court held that a database containing fixture lists for the English and Scottish football leagues did not meet the substantial investment threshold for sui generis protection. ${ }^{38}$ Courts in other EU member states adopted a different approach in determining "substantial investment". Courts in Germany, Austria and the UK all extended sui generis protection to a white pages (telephone) directory, a yellow pages (telephone) directory and a database containing information on the horse racing industry. ${ }^{39}$ The question of what exactly constitutes a "substantial investment" that qualifies for sui generis database protection was referred to the European Court of Justice in the Fixtures and British horseracing cases. ${ }^{40}$ The cases and judgments are very similar, so I will confine my description to the British Horseracing Board case.

The Horseracing Board, the governing body for horse racing in Great Britain, maintains a computerised database containing information relating to horse races

\footnotetext{
38 See Footnote 86 and Hugenholtz, Footnote 33; Fixtures Marketing Ltd. v. AB Svenska Spel, Gotland City Court 2000.

39 Tele-Info-CD, German Supreme Court 1999, I ZR 199/96, www.baukompass.at, Austrian Supreme Court 2001, 4 Ob 252/01i, British Horseracing Board v. William Hill Organisation Ltd, English High Court of Justice 2001, HC 2000 1335, [2001] All ER (D) 111.

40 Case C-203/02 (British Horseracing Board v. William Hill Organisation Ltd.), Case C-46/02 (Fixtures Marketing Ltd. v. Oy Veikkaus Ab); C-388/02 (Fixtures Marketing Ltd. v. Svenska Spel AB); C444/02 (Fixtures Marketing Ltd. v. Organismos prognostikon agonon podosfairou $\mathrm{AE})$.
} 
to be run in the country. The Board licenses the use of such information for use in Licensed Betting Offices run by firms of bookmakers. William Hill is one of the leading off-track bookmaking firms in the United Kingdom. It started to provide betting services over the Internet. The Horseracing Board sued on the basis that such use was an unlicensed use of its data and an infringement of its database rights. The judge concluded that for a "database right to exist, there must be investment in its creation and, in particular, that investment must be directed at obtaining, verifying or presenting the contents". He concluded: "William Hill's actions of taking information from [an intermediary] and loading it onto its own computers for the purpose of making it available on its website is an unlicensed act of extracting a substantial part of the [Board's] Database and the subsequent transmission of that data onto its website for access by members of the public is a re-utilisation. The defendant infringes [the Board's] rights in both ways". On appeal, the Court of Appeal indicated that it was inclined to follow the judge's views, but that some questions should be referred to the European Court of Justice for a preliminary opinion.

Among the questions to be referred were the following: (1) what constituted a database as opposed to the data contained in it; (2) whether the fact that part of a database is made available to the public through a licence arrangement has any significance in application of the database right; (3) whether a new database is created each time a database is updated. In addressing these questions the European Court of Justice concluded that: "The resources used to draw up a list of horses in a race to carry out checks in that connection do not constitute investments in the obtaining and verification of the contents of the database in which that list appears". The activities that the British Horseracing Board is engaged in require the use of resources used to "create" rather than to "obtain" information. Only substantial investments in relation to the latter activity can be protected by the sui generis database right.

It is clear that the ECJs clarification of the substantial investment criterion is not in accordance with the Commission's intent of protection non-original databases. The decision can, however, find support in the original aim of the directive, namely to protect the effort spent on creating a database, as opposed to the effort spent on creating information. This eliminates many sole-source databases from the protective effect of the sui generis right. The effect on industries that create data may therefore be considerable when it comes to generate revenues from the sale of data.
Although scientific and genuine information databases remain unaffected, they suffer the problem that resources are hard to acquire and may sometimes be funded once only. The mixing of public and private funds and resources may furthermore add insult to injury when it comes to monopolistic concerns when private parties claim their rights (EC, 2001). Yet, concerns apart, the impact of the Database Directive appears minimal in this area based on the number of cases brought, although possible negative effects on licensing practice may not be visible.

\section{The Directive as an EU export product}

The EU learned its lesson in 'gunboat diplomacy'41 when the US adopted legislation ${ }^{42}$ concerning the protection of semiconductor chip designs. Appreciating the success of this approach to set global standards, the EC Database Directive follows the example of the Council Directive on the legal protection of topographies of semiconductor products ${ }^{43}$ and also contains a reciprocity clause. Since sui generis database protection was now 'officially' outside of the scope of copyright, and therefore not subject to the Berne Convention's guiding principle of national treatment, this was not a problem. The EU Database Directive affords protection to individual database makers who are nationals or have their habitual residence in the territory of the Community. ${ }^{44}$ Similarly, rights are also granted to companies and firms formed in the Community that have their registered office, central administration or principal place of business within the Community. ${ }^{45}$ However, mere registration of an office in the territory of the Community is not sufficient, as the firm's "operations must be genuinely linked on an ongoing basis with the economy of a Member State". 46

Less clear is the status of foreign database producers. The Database Directive states that ${ }^{47}$ 'foreign' databases are eligible for protection afforded by the sui generis (sweat of the brow) right ${ }^{48}$ only, if the Council concludes an agreement extending this form of protection

\footnotetext{
${ }^{41}$ Lloyd (1997). Lloyd comments that the use of this tactic backed by the threat of force has proved effective (p. 391).

42 Semiconductor Chip Protection Act of 1984 (Pub. L. 98-620, 98 Stat. 3347, 3356), as incorporated in 17 USC Chapter 9.

43 Article 3.7 of the Council Directive 87/54/EEC of 16 December 1986 on the Legal Protection of Topographies of Semiconductor Products, OJ L 024, 27 January 1987, p. 36.

${ }^{44}$ EC Database Directive, Footnote 23, Art. 11(1).

45 EC Database Directive, Footnote 23, Art. 11(2).

46 Ibid.

47 EC Database Directive, Footnote 23, Art. 11(3).

${ }^{48}$ EC Database Directive, Footnote 23, Art. 7.
} 
for specified countries outside the EU. In other words, the basis for the protection of foreign databases is reciprocity rather than the normal rule governing copyright of 'national treatment'. The law of Mexico now provides for a sui generis protection of non-original databases.

\section{Protection of databases in the USA}

On several occasions the US Congress has attempted to introduce in US law, protection for databases that would fulfil the reciprocity requirement of the EC Database Directive. Legal initiative is necessary because databases are merely protected as "compilations" or "collective works" 49 and a requisite of originality is a threshold for protection. ${ }^{50}$ At present facts and mere data are excluded from the scope of copyright. ${ }^{51}$

Although 'sweat of the brow' or industrious collection protection has been accepted by some courts, ${ }^{52}$ the case of Feist v. Rural Telephone Services ${ }^{53}$ put the matter to rest. In Feist the Supreme Court held that:

"Although a compilation of facts may possess the requisite originality because the author typically chooses which facts to include, in what order to place them, and how to arrange the data so that readers may use them effectively, copyright protection extends only to those components of the work that are original to the author, not to the facts themselves .... As a constitutional matter, copyright protects only those elements of a work that possess more than de minimis quantum of creativity. Rural's white pages, limited to basic subscriber information and arranged alphabetically, fall short of the mark. As a statutory matter, 17 U.S.C. sec. 101 does not afford

\footnotetext{
49 See, Nimmer on Copyright $\S 2.04$ [C]: "The statutory definition of 'literary works' is broad enough to include computer data bases and programs. .." See, however, Joan F. Lane d.b.a. Lane \& Co v The First National Bank of Boston and others, 687 F. Supp. 11; [1988] Copyright Law Decisions 26,328 (Dist. MA, 1988), p. 16 (compilation copyright can apply to databases); Denicola (1981), who asserts that "databases are, in essence, automated compilations" (p. 531).

50 The US Copyright Act requires a "selection, arrangement or coordination". See 17 USC s. 103 (b).

5117 USC s. 103.

52 Leon v. Pacific Telephone \& Telegraph Co., 91 F.2d 484 (9th Cir., 1937), held that names and addresses taken from a telephone directory for compiling a directory arranged by telephone numbers infringed copyright in that source directory. On sweat of the brow see Nimmer on Copyright $\S 3.04$ [B][1], where he comments: "Protection for the fruits of such research-for the 'sweat of the author's brow' - may in certain circumstances be available under a theory of unfair competition. But to accord copyright protection on this basis alone distorts basic copyright principles, in that it creates a monopoly in public domain materials, without the necessary justification of protecting and encouraging the creation of "writings' by 'authors"'.

${ }^{53}$ See Footnote 25.
}

protection from copying to a collection of facts that are selected, coordinated, and arranged in a way that utterly lacks originality. Given that some works must fail, we cannot imagine a more likely candidate. Indeed, were we to hold that Rural's white pages pass muster, it is hard to believe that any collection of facts could fail."

This is affirmation that extraction of facts from a particular database, even for compiling a competitive database is permitted. ${ }^{54}$ In Warren v. Microdos, ${ }^{55}$ compilation copyright was clarified with respect to a computerised database. Hence, a massive extraction of data items from a printed directory for compiling a database was allowed. The data entries are unprotected facts and therefore the plaintiff's 'sweat of the brow' argument on this issue could not prevail in light of the Supreme Court's Feist decision, a decision that was later affirmed in Campbell v. Acuff-Rose Music Inc. ${ }^{56}$

The Feist decision also cast a shadow over the methods available to the US legislator to provide protection for databases on a par with the EC Database Directive's sui generis right. Protection of databases can no longer be based on quasi-property, but has to be based on unfair competition law, based on the commerce clause.

\section{Bills, bills, bills}

From 1996 several bills have been introduced to provide for database protection for non-original databases in the United States. Conflicting bills were introduced, withdrawn, amended, reintroduced, and ultimately put aside. ${ }^{57}$ In view of the current evaluation process in the EU, any attempt to rekindle the US database initiative would have to be internally driven and is unlikely. In any event EU database development and practice has had a limited impact on the discussion in the US.

The first bill, ${ }^{58}$ which was roughly drafted on the provisions of the Database Directive, went beyond the Directive's measures regarding its scope of protection.

\footnotetext{
$\overline{54}$ Bellsouth Advertising \& Publishing Corp v. Donnelley Information Publishing Inc and another, 1999 F.2d 1436; 28 USPQ 2d 1001.

55 Warren Publishing Inc v Microdos Data Corp and others, [1992] CCH Copyright Law Decisions 26,928; 3 CCH Computer Cases 46,683 (Dist., Northern District of Georgia, Atlanta Division, 1992). The Judgment of the District Court was affirmed in 52 F. 3d 950 (11 th Cir., 1995), but that decision was subsequently vacated by a grant of rehearing in 67 F. 3d 276 (11th Cir., 1995). Finally, the District Court decision was vacated and remanded, see 115 F. 3d 1509; Copyright L.R. 27,667 (11th Cir., 1997). The petition for a writ of certiorari was denied by the Supreme Court, see 118 S. Ct. 397 (1997).

56510 U.S. 569, 575 (1994).

57 See Band (2005).

${ }^{58}$ H.R.3531, 104th Congress, 2nd Session (1996).
} 
For instance, the proposed term of protection was 25 years $^{59}$ as compared to 15 years in the Database Directive. No corresponding Bill was introduced in the Senate, no actions were taken in relation to this Bill and the Bill failed.

H.R.354, the Collections of Information Antipiracy $\mathrm{Act}^{60}$, was adopted by the House Committee on the Judiciary 1999 during the 106th United States Congress, and appeared to stand a chance of success. It superseded H.R.2652, ${ }^{61}$ a 1997 attempt at introducing database protection. H.R.354 was based on the concept of misappropriation and would have prohibited extraction of information from a database for the purpose of re-utilisation, or dissemination for use in commerce, or use harming substantially the database producer's primary market. Database owners would have enjoyed the right to prevent certain acts of extraction of information from their database for uses of information into downstream products, whether or not they compete with the database. ${ }^{62}$ It should be noted that in the drafts towards the enactment of the Digital Millennium Copyright Act, ${ }^{63}$ the text of this US Database Bill was incorporated. ${ }^{64}$ However, this text concerning database protection was dropped as the final draft of the Act was passed. ${ }^{65}$

\footnotetext{
59 Ibid., $\S 6(a)$.

60 See Footnote 2.

${ }^{61}$ H.R. 2652, 105th Congress, 2nd Session, introduced on 9 October 1997. The Bill was passed by the House of Representatives on 19 May 1998 (C.R. H3404) and was received in the Senate on 20 May 1998 for further legislative action.

${ }^{62}$ H.R.354.RH. Sec. 1402. Prohibition: "(a) MAKING AVAILABLE OR EXTRACTING TO MAKE AVAILABLE - Any person who makes available to others, or extracts to make available to others, all or a substantial part of a collection of information gathered, organised, or maintained by another person through the investment of substantial monetary or other resources, so as to cause material harm to the primary market or a related market of that other person, or a successor in interest of that other person, for a product or service that incorporates that collection of information and is offered or intended to be offered in commerce by that other person, or a successor in interest of that person, shall be liable to that person or successor in interest for the remedies set forth in section 1406. (b) OTHER ACTS OF EXTRACTION - Any person who extracts all or a substantial part of a collection of information gathered, organised, or maintained by another person through the investment of substantial monetary or other resources, so as to cause material harm to the primary market of that other person, or a successor in interest of that other person, for a product or service that incorporates that collection of information and is offered or intended to be offered in commerce by that other person, or a successor in interest of that person, shall be liable to that person or successor in interest for the remedies set forth in section 1406."

63 H.R. 2281, 105th Congress, 2nd Session.

${ }^{64}$ Ibid. Title V.

65 DMCA 1998, Public Law 105-304. The Act was signed by the President on 28 October, 1998.
}

This is due to the fact that competing bill H.R.1858, the Consumer and Investor Access to Information Act, ${ }^{66}$ was passed by the House Committee on Commerce during the 106th Congress too. It would have provided protection for databases by addressing direct competitors only. At first glance H.R.1858 was narrower in its scope of application than H.R.354. H.R.1858 would have afforded protection against misappropriation to a limited range of subject matter only, ${ }^{67}$ leaving a large part of the real-time information database market exposed to misappropriation. ${ }^{68}$ Furthermore, H.R.1858 recognised a limited form of protection of databases against slavish copying by duplication of extracted information. The definition of what constitutes a database, however, was so wide, bordering on the infinite, as it also encompasses discrete sections of databases that contain multiple discrete items. ${ }^{69}$ In addition, a wide definition of 'in competition' when it comes to confining the unauthorised sale or distribution of a duplicate of a database that is essentially the same as the original was only off-set by the possible application of antitrust measures ${ }^{70}$ and not by a limitation of term.

A choice between these two bills was not made and the House Committee on Rules and the House Republican leadership urged the two committees that had introduced both bills to reach a consensus, but no consensus was reached before the end of the 106th Congress in 2000. The Database debate continued throughout the sessions of the 107th and 108th Congress. More bills were introduced $^{71}$ (see Band, 2005), but they all suffered the fate of the previous ones.

The basic problem is that all efforts are potentially liable to a constitutional challenge (see Pollack, 1999). Intellectual property rights are based on the patents and copyright clause $\mathrm{e}^{72}$ empowering Congress to legislate in

\footnotetext{
${ }^{66}$ H.R.1858 of 19 May 1999.

${ }^{67}$ H.R.1858 speaks of protection against misappropriation of securities market and real-time market information that is sold, distributed or disseminated without authorisation.

68 One can think of exchange rates, score results in sports games, news feeds, etc.

69 Congressional Record E1055 (20 May 1999); H.R.1858 S. 101(1) states that a discrete section of a database may also be treated as a database. This means, for example, that if a directory of restaurants in the District of Columbia is organised by type of food, the section comprising Italian restaurants could constitute a database within the meaning of the Bill, even though it is part of a larger database (i.e. the D.C. restaurant directory).

${ }^{70}$ H.R. 1858 S. 107.

71 H.R. 3261, the Database and Collections of Information Misappropriation Act; and H.R. 3872, the Consumer Access to Information Act.

${ }^{72}$ U.S. CONST. art. $1, \S 8$, cl. 8.
} 
this area. The intellectual property clause not only preempts the State's efforts to create quasi-intellectual property rights, ${ }^{73}$ but also limits the power of Congress itself to do so when it does not involve "original contributions to the wealth of human knowledge" ${ }^{74}$ This limitation reiterated in the Feist decision (Ginsburg, 1992; Pollack, 1999), forces database legislation to be based on the commerce clause. ${ }^{75}$ This means that functional equivalence to the EC Database Directive may never be achieved in the US.

\section{Misappropriation and unjust enrichment}

How to address the specific needs of database producers that stand to lose their income should users be allowed to plunder all or a substantial part of a database so that they have no need to consult the database again? It is hard to see that this form of protection is based on anything other than unfair competition market failure theory. Although the concept of misappropriation has enjoyed limited application since its inception in the case International News Service v. Associated Press, ${ }^{76}$ it is clearly rooted in unfair competition law. Such protection is not dependent on proprietary concepts like other branches of protection of intellectual and industrial creativity, but on legal concepts such as unjust enrichment (Callmann, 1942; Sanders, 1997, Chapter 1) and economic concepts such as asymmetric market failure. ${ }^{77}$

Most unfair competition statutes and case law around the world, ${ }^{78}$ and indeed also the WIPO Model Provisions on Protection Against Unfair Competition, ${ }^{79}$ use a wide notion of competition for the purpose of market regulation, addressing also acts where there is no direct competitive nexus, but where the plaintiff's primary market is nevertheless directly and fundamentally affected. Since much of the database producer's value-added to the database consists of providing access and context (struc-

\footnotetext{
${ }_{73}$ Bonito Boats Inc. v. Thunder Craft Boats Inc., 489 U.S. 141 (1989); Sears, Roebuck \& Co. v. Stiffel Co., 376 U.S. 225 (1964); Compco Corp. v. Day-Brite Lighting Inc., 376 U.S. 234 (1964). For an assessment see Sanders (1997, pp. 12-19).

74 See Feist, Footnote 25.

75 U.S. CONST. art. 1, $\S 8$, cl. 3 . See also Conley et al. (2000).

76248 US 215 (1918). For an overview of the nature and development of unfair competition law see Sanders (1997); on legal reasoning in unfair competition law see Ohly (1997); for France see Passa (1997); for Switzerland see Berger (1997); and for Germany see Beater (1995).

77 Sanders (1997, Chapter 4), Gordon (1992a,b), Karjala (1994, pp. 2594-3609), and Reichmann (1994).

78 See Footnote 79.

79 No. 832(e) (Geneva, WIPO, 1996, and also Protection against Unfair Competition, No 725(e) (Geneva, WIPO, 1994).
}

ture, reliability and exhaustiveness) to information, only parasitic acts of destruction to this qualitative or quantitative investment are to be regulated. It is submitted that it would be desirable if the EC Database Directive were to be amended so as to spell out its confinement to this principle.

When considering exclusive rights to prevent extractions used in enhanced or derivative products (i.e. databases that are not exact duplicates of the original, but add other information), an argument can be made that this type of protection falls within intellectual property and not competition law (Benkler, 2000, p. 571). Again, this interpretation of unfair competition law is rather narrow, but it underlines the legitimate concern for pricing, as well as dependence on one or a limited number of relevant databases. ${ }^{80}$ At one point the EC Database Directive was set to have its own provision on compulsory licensing ${ }^{81}$ in relation to the sui generis right, but this was dropped. In EU cases involving databases, however, the single source issue ${ }^{82}$ has been raised as defence to sui generis database protection claims. ${ }^{83}$

Whereas monopoly pricing is left to antitrust authorities, reliance on intellectual property rights to safe-

\footnotetext{
${ }^{80}$ One can think of the stranglehold some publishers have over academic publications, as well as certain professional disciplines that depend on information.

${ }^{81}$ Proposal for a Council Directive on the Legal Protection of Databases, Art. 8, COM (92) 24 def. Art 70.

82 Dutch Competition Authority Case no. 1/Holdingmaatschappij De Telegraaf v. Nederlandse Omroep Stichting and Holland Media Groep 16 Feb. 2000 (http://www.nma-org.nl/).

${ }^{83}$ KPN Telecom B.V. v. Xbase Software Ontwikkeling B.V., Pres. Distr. Ct. The Hague, 14 Jan. 2000, KG 99/1429, [2000] 2 Mediaforum 64, [2000] 4. Informatierecht/AMI 71 which involved a software program running on the world wide web that allowed users to extract information from the KPN database containing telephone numbers, bypassing the advertising banners. This was held to be a clear infringement of the Database right; conversely see Vermande B.V. v. Bojkovski, Pres. Distr. Ct. The Hague 20 March 1998, [1998] IER 111; Denda v. KPN, Court of Appeal Arnhem 15 April 1997 \& 5 August 1997, [1997] 5 Mediaforum B72, [1997] Informatierecht/AMI 214. In the Telco cases the point was also advanced that the investments made were not primarily geared towards the creation of databases of phone numbers. The argument that spin-off databases should not be protected for lack of substantial investment was not accepted. See, however, Telegraaf/NOS and HMG, Netherlands Competition Authority, 10 September 1998, (1998) Mediaforum 304; and NOS v. De Telegraaf, Court of Appeals of The Hague 30 January 2001, (2001) Mediaforum 90, both cases involving a refusal to license broadcasting information. Ultimately the Court of Appeals held that the broadcasters did not enjoy database right protection for their listings, as substantial investment in the making of the database, above and beyond any investments in the programming as such, had not been shown. Copyright for non-original writings was, however, granted, but the refusal to license was held to constitute anticompetitive behaviour.
} 
guard assets and associated pricing is generally left unaffected. ${ }^{84}$ Intellectual property policy and antitrust policy are still perceived as separate domains.

\section{Trespass and Contract Law as alternatives}

As noted above, the Feist case has effectively denied US copyright protection to many databases. In view of the arrested development in database protection, some US jurisdictions have tried to resolve issues of market failure resulting from lack of access control to databases through the venerable tort of trespass to goods. ${ }^{85}$ In the case of eBay v. Bidder's Edge ${ }^{86}$, Bidder's Edge, an auction aggregation site, utilised software robots to access eBay 100,000 times per day, burdening their system capacity. eBay moved for preliminary injunctive relief to prevent Bidder's Edge from accessing eBay based on nine causes of action, including copyright infringement. The Court, however, moved in a totally different direction when it found for eBay based on a trespass to chattels claim. The preliminary injunction issued prevented Bidder's Edge from accessing eBay altogether without written authorisation. In effect this type of protection is even stronger than the sui generis right under the EC Directive, since trespass is committed merely by access and, subject to proof of special damage, does not require any extraction at all.

Another possibility lies in the application of contract law. The use of information products may be limited by express contractual agreement setting the terms for delivery of the information service, but also through use of shrink-wrap licences connected to the information product. ${ }^{87}$ In the US case of ProCD v. Zeidenberg ${ }^{88}$ defendants Matthew Zeidenberg and Silken Mountain Web Services Inc., purchased copies of the plaintiff's Select Phone TM CD-ROM software program and downloaded telephone listings stored on the CD-ROM discs

\footnotetext{
$\overline{84}$ The rightholder is therefore permitted to maximise income. Only on cases of price discrimination between classes of purchasers are authorities prepared to act. For an overview of the plethora of means a marketer has at his disposal and the way in which US courts have reacted see Varian and Shapiro (1999), Shapiro (1999, pp. 1-11), and Katz and Shapiro (1998).

${ }^{85}$ See Thrifty-Tel v. Bezenek 54 Cal Rptr 2d 468 (1996); eBay v. Bidder's Edge 100 F Supp 2d 1058 (N D California, 24 May 2000). See, also, Adams (2002), who argues that the correct form of action should have been trespass on the case and Hardy (1996).

86 Ibid.

87 See Samuelson and Opsahl (1998, pp. 163-193) on Article 2B proposal of the Uniform Commercial Code.

88 ProCD Inc. v. Matthew Zeidenberg, and Silken Mountain Web Services 86 F 3d 1447 (7th Cir. 1996).
}

to Zeidenberg's computer. Zeidenberg made these listings available to Internet users by placing the data onto an Internet host computer. In support of their copyright infringement claims, breach of the express terms of the parties' software licensing agreement was part of the claim. Zeidenberg argued that the data they downloaded from plaintiff's program were not protected by copyright and that they were not bound by the software licensing agreement. The Court accepted that, in principle, end-user licences are enforceable when the user breaks the plastic film wrapped around a software package, but held that Zeidenberg had not been offered reasonable opportunity to take cognisance of the licence terms, because they were inside the box. The Zeidenberg judgment prompted the American Law Institute, drafters of proposed new US Uniform Commercial Code (UCC), to suggest a provision following the ProCD judgment, that would make standard form licences enforceable if: "prior to or within a reasonable time after beginning to use the intangible pursuant to an agreement, the party signs or otherwise by its behaviour manifests assent to a standard form licence; and had an opportunity to review the terms of the licence before manifesting assent, whether or not it actually reviewed the terms".

At the time the UCC revision has sparked controversy over whether contract law can and should override copyright law. ${ }^{89}$ The controversy continues, but the principle that contract law can enhance the rights of authors as well as producers of databases remains an important principle.

\section{In search of a horizontal right to information-competitors}

Whereas monopoly pricing is left to antitrust authorities, reliance on intellectual property rights to safeguard assets and associated pricing is generally left unaffected. ${ }^{90}$ Intellectual property policy and anti-trust policy are still perceived as separate domains. Protection against misappropriation, however, is a distinct branch of competition law in that it is based on investment and return analysis and market failure assessment. Disguised beneath all the proprietary language even the EC Database Directive demands such assessment when it

\footnotetext{
${ }^{89}$ See Samuelson and Opsahl (1998, pp. 163-193) on Article 2B proposal of the Uniform Commercial Code.

90 The rightholder is therefore permitted to maximise income. Only in cases of price discrimination between classes of purchasers are authorities prepared to act. For an overview of the plethora of means a marketer has at his disposal and the way in which US courts have reacted see Katz and Shapiro (1998).
} 
comes to the question of qualification for the sui generis right, as well as that of assessment of infringement. It is submitted that, because of its roots in competition law, database protection should follow the contours of market reality and should, therefore, contrary to intellectual property rights proper, be subject to a higher level of scrutiny when it comes to anti-trust policy.

In their work Information Rules, Varian and Shapiro (1999) succinctly describe the characteristics of the network economy, pointing to the fact that there are many more factors, such as network effects, tying, bundling, lock-in and switching costs, versioning, and encryption technologies ${ }^{91}$ that may also serve as barriers to access to and free flow of information goods. Some argue $e^{92}$ that in the new economic reality old economic axioms do not apply, as new information products possess different characteristics, which means regulators should stay well away from this emerging market. Others ${ }^{93}$ argue that normal scenarios still apply. The Microsoft cases, however, show that the latter position is still prevalent. ${ }^{94}$ Whereas there may be a certain reluctance to impose a duty on intellectual property rightholders to provide essential facilities, ${ }^{95}$ the creation of a horizontal right to information may be construed under the essential facilities doctrine when there is only a veritable source available.

\section{Monopoly power-abuse of a dominant position}

Just as there are compelling arguments for the protection of a trader's market through property-or liabilityrule systems, there is also a compelling argument for the curbing of abuse of monopoly power resulting from either system. Whereas any monopoly leads to a situation in which market entry for new entrants is restricted, the abuse of monopoly power does so without heeding the justifiable reasons for restricting market entry for new incumbents, which can be found in the incentive- and reward-based paradigms. Instead the undertaking uses its monopoly right to seek excessive rents in an abusive manner through its position of dominance. Article 82 of

\footnotetext{
91 These techniques may be applied to the underlying software, but also to the data itself.

92 See the contributions of Reback and Kelly to Wired, August 1997; see also Kelly (1998).

93 See Footnote 87.

94 Posner (2000), available at http://www.techlawjournal.com/atr/ 20000914posner.asp.

95 Katz M. and Shapiro C., Footnote 87, at 39 when discussing interfaces in software markets.
}

the EC Treaty has the effect that in those circumstances in which an undertaking abuses its dominant position in the market, that undertaking may be forced not to exercise its monopoly power. ${ }^{96}$ In United Brands Co. and United Brands Continental BV v. EC Commission ${ }^{97}$ a dominant position was described as: "a position of economic strength enjoyed by an undertaking which enables it to prevent effective competition being maintained on the relevant market by giving it the power to behave to an appreciable extent independently of its competitors, customers and ultimately of its consumers". It is appropriate to point out here that intellectual property rights may contribute to a large extent to the dominant market position an undertaking can achieve and lead to a situation where an undertaking's market share, either in itself or when combined with its know-how, access to raw materials, capital or other major advantage such as trademark ownership, enables it to determine the prices or to control the production or distribution of a significant part of the relevant goods. It is not necessary for the undertaking to have total dominance such as would deprive all other market participants of their commercial freedom, as long as it is strong enough in general terms to devise its own strategy as it wishes, even if there are differences in the extent to which it dominates individual sub-markets.

It is equally appropriate to point out that the mere existence and exercise of an intellectual property right as such does not constitute an abuse, since it is a legally recognised exclusive right to reproduction that is a restriction on competition which is devised to create a market for an intangible in the first place. This point can be found in many abuse cases. ${ }^{98}$ It is therefore important to distinguish between the existence of intellectual property rights conferred by national legislation of a Member State, which is not affected by the EC Treaty, the exercise of the 'specific subject matter', which is a justifiable restriction on the freedom of trade but may come within the prohibitions of the Treaty 99 , and the use of market power, which may also come within the prohibitions of the Treaty. ${ }^{100}$ Over a number

\footnotetext{
96 For a description see Korah (1994).

97 (Case 27/76) [1973] ECR 215.

${ }^{98}$ Etablissements Consten SA \& Grundig-Verkaufs-GmbH v. EC Commission (Case 56/64) [1966] ECR 299, [1966] CMLR 418; Deutsche Grammophon Gesellschaft GmbH v. Metro-SB-Großmärkte GmbH \& Co. KG (Case 78/70) [1971] ECR 487, [1971] 1 CMLR 631.

${ }^{99}$ Ibid. See also Article 30-36 of the Treaty of Rome. For a description see Green (1993) and Tritton (1996, Chapter 7).

100 Radio Telefis Eireann and Independent Television Publications v. EC Commission (Cases C241 and 242/91) [1995] ECR I-743.
} 
of years the European Court of Justice (ECJ) developed the doctrine of the 'immune exercise', meaning that an exercise of a right corresponding with the core of an intellectual property right cannot in itself constitute an abuse. ${ }^{101}$ 'Specific circumstances' are needed in order to make the exercise abusive. These additional 'specific circumstances' may be abuses of market power that are clearly separate from the existence/exercise of an intellectual property right, ${ }^{102}$ or certain exercises of rights related to intellectual property rights, such as licensing and demanding royalties, which fall within the subject matter of the right. Within this latter category the boundaries of what is part of the existence, the exercise, and the specific subject matter is not evident. ${ }^{103}$ It is not at all clear to what extent such exercises are subject to Art. 82 of the Treaty. As a consequence the question as to whether a refusal to licence on the basis of an intellectual property right constitutes an abuse is not self-evident, for it presupposes that the aims of Community competition law are included in the essential function of an intellectual property right. The position of the ECJ on this matter has been described by a leading academic as having evolved from a hostile attitude towards IPRs, as evidenced in the Magill case, towards recognition of the importance of IPR as a means to stimulate investment in innovation. ${ }^{104}$ The reasons for the early hostility are said to have been brought about by the influence of the ordoliberal thinking of the school of economics in Freiburg. As a backlash to the Nazi ideas, the pursuit of liberty was to be effectuated by the dispersion of political and economic power. Patent monopolies were not only seen as an economic power that ought not be exercised, they

\footnotetext{
$\overline{101}$ Parke Davis \& Co. v. Probel (Case 24/67) [1968] ECR 55, [1968] CMLR 54.; Hoffman-La Roche \& Co. AG v. Centrafarm Vertriebsgesellschaft Pharmazeutischer Erzeugnisse GmbH (Case 102/77) [1978] ECR 1139, [1978] CMLR 217; Consorzio Italiano della Componentistica di Ricambio per Autoveilici (CIRCA) and Maxicar v. Régie Nationale des Usines Renault (Case 53/87) [1988] ECR 6039, [1990] 4 CMLR 265; Volvo AB v. Erik Veng (UK) Ltd. (Case 237/87) [1988] ECR 6211, [1989] 4 CMLR 122.

102 One can think of practices such as tying, discriminatory policies, refusal to supply customers who might resell, refusals to honour guarantees and operating, secretly and unilaterally, a policy of differential discounts. This was the case in Case C-53/92P (Hilti AG v. EC Commission) [1992] 4 CMLR 16, an appeal from Commission Decision 22 December 1987, Cases 30/787 and 31/488 (Eurofix-Bauco v. Hilti AG) [1989] 4 CMLR 677, where eight distinct abuses were put forward, all of which were exercises of market power, not of patent rights, although one of the abuses consisted of the frustration or delay of legitimately available licences under Hilti's patent, by demanding exorbitantly high royalties.

103 As pointed out by Miller (1994).

104 Korah (2001).
}

were also evaluated ex post in terms of their efficacy to ensure incentives to invest, leading to a situation where: "By the time an intellectual right holder exercises its rights, the investment that led to the right is water under the bridge". ${ }^{105}$ Limitations to intellectual property rights were thus not perceived as reductions to the incentive to make the investment leading up to the existence of these rights.

\section{Refusal to license or supply}

In Commercial Solvents, ${ }^{106}$ the case revolved around a refusal by Commercial Solvents to supply Zoja with the raw materials to make ethambutol, a drug used for the treatment of tuberculosis. Commercial Solvents was the only commercial player in this market possessing the knowledge to make the raw material and had been supplying Zoja in the past. When Commercial Solvents obtained half an interest in Istituto Chemioterapico, the only other producer of ethambutol, it changed its policy on supplying Zoja. The ECJ held that this refusal amounted to an abuse of a dominant position, and that its condemnation of the refusal was prompted by a desire to protect a small firm rather than free competition for the benefit of consumers.

In Volvo AB v. Erik Veng (UK) Ltd., ${ }^{107}$ rights within the specific subject matter of design rights ${ }^{108}$ were exercised in 'special circumstances'. 109 Because he was refused a licence, the defendant imported spare parts (front wings) for the Volvo 200 series from Italy and Taiwan via Denmark into the United Kingdom, where

\footnotetext{
$\overline{105 \text { Ibid. at }} 803$.

106 Istituto Chemioterapico Italiano SpA v. Commission, Cases 6 \& 7/73, [1974] ECR 223, [1974] 1 CMLR 309, CMR 8209.

107 See Footnote 104.

108 For the definition of specific subject matter of patents as the reward for inventive effort, see Centrafarm BV and De Peijper v. Sterling Drug Inc. (Case 15/74) [1974] ECR 1147, [1974] 2 CMLR 480; For trademarks see Hoffman-La Roche \& Co. AG v. Centrafarm Vertriebsgesellschaft Pharmazeutischer Erzeugnisse GmbH fn. 25 above, defining as the essential function of a trademark the guarantee of the origin of the product. See Ciné Vog Films v. CODITEL (Compagnie Générale pour la Diffusion de la Télévision) (Case 62/79) [1980] ECR 881, [1981] 2 CMLR 362, where the right to demand a royalty for the public performance of a work was held to be an essential function of copyright, a position rejected by the AG in Magill. The difference between 'specific subject-matter' and the 'essential function' of intellectual property rights is not always clear, nor is the relevance for making it. See in this respect Gulmann AGs Opinion in Magill, S. Haines, 'Copyright Takes the Dominant Position' [1994] 9 EIPR 401, 402.

109 See the definition in Hoffman-La Roche \& Co. AG v. Centrafarm Vertriebsgesellschaft Pharmazeutischer Erzeugnisse GmbH, Footnote 104.
} 
these parts were protected under the Registered Designs Act 1949. In considering the exercise by Volvo of its intellectual property right, the ECJ stated that to oblige "the holder of a protected design to grant third parties a licence to supply products incorporating the design, even in return for reasonable fees, would result in depriving the holder of the substance of its exclusive right", but that nevertheless Volvo's refusal amounted to an abuse of its dominant position. This was because Volvo itself was no longer producing the parts in question and thus created market conditions that obliged the consumer to buy a new car, where the old model was still in circulation. Whereas in Volvo the 'specific circumstances' elevate the exercise of a design right to an abusive exercise, the distinction between existence and exercise is not so clear in the Magill case. ${ }^{110}$ The case concerned the exercise of copyright in broadcast listings in the United Kingdom and Ireland, which the television broadcasters RTE, BBC and ITV provided on a daily basis free to newspapers. Weekly listings were provided by each broadcaster in separate television guides. When an Irish publisher, Magill, launched its comprehensive weekly guide, it was faced with an injunction by the Irish courts on the basis of the broadcasters' respective copyrights. When the ECJ finally upheld the decisions of the Commission and the Court of First Instance, both holding that the broadcasters had indeed abused their dominant position in holding that the reliance on copyright amounted to the monopolisation of a derivative market, much thought was given by commentators to the question as to whether the ECJs judgment presents an overly broad incursion into the "immune exercise" of the broadcaster's copyright. ${ }^{111}$ It is important to note at this point that the protection of moral rights and the ensuring of a reward for creative effort were judged to be within the "essential function" of copyright, but that the approach taken in Coditel, ${ }^{112}$ where the right to demand a royalty for the public performance of a copyright work was held to be an "essential function", was not adopted. ${ }^{113}$

\footnotetext{
110 See Footnote 103.

111 See Miller (1994), Van Kerckhove (1995), Calvet and Desurmont (1996) and Haines (1994).

112 Ciné Vog Films v. CODITEL (Compagnie Générale pour la Diffusion de la Télévision) Footnote 112; and CODITEL (Compagnie Générale pour la Diffusion de la Télévision) v. Ciné Vog Films (No 2) (Case 262/81) [1982] ECR 3381, [1983] 1 CMLR 49.

113 See on this point Miller (1994, p. 418), where Miller attributes much of the controversy surrounding the Magill case to the incorrect application, as he sees it, of this distinction by the ECJ. It can be suggested that the ECJs assessment of the abusive adverse effects on competition, which, according to the Court, lay in the monopolisation of a market in weekly television guides by exercise of copyright in
}

This factor notwithstanding, Magill prompts the question of what the "special circumstances" were that made the otherwise legitimate exercise by the broadcasters of their copyright in their refusal to grant a licence an exercise of a dominant position that is abusive. Commentators have looked at Magill on the basis of parallels with Volvo, ${ }^{114}$ stating the refusal to licence in that case amounted to an obstruction of the reproduction of products; Magill involved the monopolisation of a derivative market. By the exercise of its copyright, Magill would not only retain its primary product; it would also prevent the production of comprehensive television guides based on raw data and thus impair the genesis of a new market. ${ }^{115}$ This is why Magill is not so much a refusal to licence case, as a refusal to supply case, ${ }^{116}$ comparable to Commercial Solvents Corp. and Istituto Chemioterapico Italiano SpA v. EC Commission. ${ }^{117}$ This distinction is important to the Court's finding of "exceptional circumstances", 118 which rendered the broadcasters' behaviour abusive. The fact that raw data are susceptible to copyright in the United Kingdom if incorporated in an original literary work, ${ }^{119}$ stems from a nationally recognised right, the exercise of which is within the essential function of copyright. This could not be seen to be the basis for the ECJs decision. The Court is indeed silent on the matter, but one cannot help thinking that at the back of the Court's mind were the provisions on decompilation in the Council Directive on the Legal Protection of

raw data, was in fact a covert attempt by the ECJ to interfere with the immune exercise of UK copyright, which happens to grant protection, where other Member States do not. See also the Broadcasting Act 1990, s. 176.

114 See Footnote 104; Haines, Footnote 111.

115 Treaty of Rome Article 86(b) defines it as dealing with abuse consisting in "limiting production, markets or technical development to the prejudice of consumers".

116 Van Kerckhove (1995).

117 (Cases 6 7/72) [1974] ECR 224, [1974] 1 CMLR 309, a case in which the applicants produced the raw materials nitropropane and aminobutanol, needed for the production of ethambutanol, which was subsequently used in the production of a tuberculosis drug. The applicant refused to sell aminobutanol to a competitor because it wanted to enter the derivatives market itself. This refusal to sell essential raw materials to a competitor was held to be an abuse of a dominant position.

118 It is interesting to note that the ECJ speaks of 'exceptional circumstances' and not of 'special circumstances'. This displays the extraordinary position Magill takes in the Art. 86 case law and supports the position taken by Calvet and Desurmont (1996).

119 Mallet-Poujol (1996, p. 138): "[T]he Magill case reveals plainly the impasses to which an incorrect application of copyright leads, through a lax assessment of the originality of programme listings and doubtless a poor understanding of the implementation of the reproduction right". 
Computer Programs, ${ }^{120}$ and the compulsory licensing provisions that were part of the Database Directive as proposed at the time. ${ }^{121}$ Exercise of a dominant position supported by intellectual property rights, resulting in the creation of extremely high barriers to entry for new market entrants, can thus be mediated by Article 86 of the Treaty of Rome. It is, however, important to realise that the modifying effects of the essential facilities doctrine can only be relied upon if a refusal to licence or supply results in an exclusion of competition in a secondary market.

In Oscar Bronner v. Mediaprint ${ }^{122}$ the ECJ accepted that a supply service consisting of a home-delivery scheme for daily newspaper media constitutes a separate market. The Advocate General's opinion insisted that supply of facilities should be essential to enter downstream markets, but spelled out that compulsory licences to provide access to assets should be rare, particularly in view of the maintenance of incentives for investment. ${ }^{123}$ He furthermore enunciated that the objective of competition law is to protect consumers, rather than particular competitors, limiting the rationale for compulsory licensing. The Advocate General's opinion seems to have been persuasive. On the question of whether a refusal by Mediaprint, owner of the only nationwide Austrian home-delivery scheme, to allow rival publisher Oscar Bronner access to the service against payment of reasonable remuneration constitutes an abuse of a dominant position, the Court answered negatively. The Court construed Magill narrowly and said it was an exceptional case, ${ }^{124}$ holding that even if it applied to other property rights than intellectual property rights, to find an abuse Oscar Bronner would have to establish: that the refusal would be likely to eliminate all competition in the daily newspaper market; that the refusal could not be objectively justified; and that the service be indispensable to carrying on Oscar Bronner's business, in that there was no potential substitute.

Mediaprint's refusal was held not to eliminate all competition in the daily newspaper market, and would also not create technical, legal or economic obstacles, making it impossible to establish a competing home-

\footnotetext{
${ }^{120}$ Council Dir. 91/250/EEC of 14 May 1991, [1991] OJ L122/42.

121 See Cook (1996) on the removal of the provisions relating to compulsory licensing of commercially exploited databases that form the sole source of data from the final Dir. in the light of the Magill decision. 122 Case C-7/97 (Oscar Bronner GmbH Co., KG v. Mediaprint Zeitungs/und Zeitschriftenverlag GmbH Co. KG) [1998] ECR I-7817, [1999] 4 CMLR 112, [1999] CEC 53.

123 See Footnote 122, para 64.

124 See Footnote 122, paras 39-41.
}

delivery scheme. Access to the home-delivery scheme was, in this sense, not an essential facility. ${ }^{125}$

The EC Commission brought essential facilities to the fore once more in the case of IMS Health, ${ }^{126}$ when it required that a licence be given on a business method that a German court had held subject to copyright protection. The business method consisted of the compilation of information on sales and prescriptions of pharmaceutical products according to a 'brick' structure, whereby the German territory was divided into 1860 zones, the scope of each of which was determined by the weighing of utilitarian and data protection considerations. This means that a minimum of three pharmacies need to be included in each zone to prevent tracing of individual data, whereas a maximum of four or five is required to keep the database structure stable and useful. IMS received help and information from pharmaceutical companies in establishing the brick structure, but subsequently invested in the system by fine-tuning the zones and adding new ones after German reunification. Until 1999 IMS was the sole provider of regional data, but two new market entrants, NDC and AzyX, subsequently entered the market, using their own zone system. NDC and AzyX soon found that their information system met with resistance because of the territorial divisions already in use by pharmaceutical companies. In other words, the customers were not able or willing to make the switching costs. NDC and AzyX then started using the IMS brick system and were successfully sued by IMS. The Commission, however, required IMS to grant a licence in the geographical arrangements that make up the brick system. The compulsory licence was contested and the European Court of Justice was asked for guidance. In its decision of 29 April 2004, 72 the ECJ considers, that the refusal to license an industry standard in the absence of a reasonable alternative may constitute an abuse of a dominant position. In answering the question whether there is abusive behaviour, a national judge will have to take into account the fact that the pharmaceutical industry itself participated in setting and improving the standard it has become dependent on. This may result in significant switching costs that will make

\footnotetext{
${ }^{125}$ In view of the emerging US practice of patenting business methods, however, it is easily conceivable that even delivery schemes may become essential facilities. See Amazon.com v. Barnesandnoble.com 73 F. Supp.2d 1228, 53 USPQ2d 1115 (W.D. Wash. Dec. 1, 1999); and State Street Bank and Trust Co. v. Signature Financial Group, Inc. 927 F.Supp.502, 38 USPQ2d 1530 (D. Mass. 1996).

126 Case COMP D/338.044 (NDC Health/IMS Health: Interim Measures) (July 3, 2001), [2002] 4 CMLR 111, available at http://europa.eu. $\mathrm{int/comm/competition/antitrust/cases/decisions/38044/en.pdf.}$
} 
it difficult for a new market entrant to offer a viable alternative.

Whether a refusal to license an intellectual property right constitutes an abuse of a dominant position should, according to the ECJ, be answered according to the three cumulative criteria of its Magill decision, namely that refusal: (1) prevented the emergence of a new product for which there was a potential consumer demand; (2) was not justified by objective considerations; (3) was likely to exclude all competition in the secondary market. Although Magill still spoke of two separate markets, the ECJ now considers that it is not necessary to identify two distinct markets. It is enough that there is a potential, or even hypothetical market, where it is possible to discern two distinct, but interrelated stages of production. It is hard to see a separate market for the copyright work consisting of 1860 zones that has a separate economic significance without the database of which it is the defining structure. By introducing the notion of stages of production it is, however, still possible to speak of a primary market for the building block and a secondary market for the finished commercial product. The end result is that IMS has to compete on the market where it is economically active, that of the finished product. ${ }^{127}$ There is, however one important limitation to the purpose of the compulsory licence. That is that the licensee cannot be engaged in duplicating the goods or services offered by the holder of the intellectual property right, but intends to offer new goods for which there is a potential consumer demand. What exactly constitutes a new product will no doubt be a contentious issue in the future.

Another element that is not yet clear is how to calculate a reasonable royalty for the compulsory licence. Cross-licensing practices have not yet developed in the copyright and database domain to the same extent as in the patent area (Dam, 1998). A compulsory licence entitles the rightholder of the main patent to a cross-licence in the derivative creation. The reason for doing so is to make sure that the first rightholder is not left with an invention that has been rendered commercially redundant by the subsequent innovation. By cross-licensing the effect of the compulsory licence is mitigated by placing the licensor in a position where he benefits from duopolistic competition by exploiting his own and the cross-licensed technology. In IMS Health a similar argument in favour of cross-licensing can be made. In other areas of copyright this is not always self-evident. A crosslicence is, for example, not useful in case of derivative works, such as translations. There is scope for others to

127 Sanders (2005), pp. 254-256. innovate without literal copying and it is possible to create new products in derivative markets that the licensor has no desire to exploit.

\section{In search of a horizontal right to information-non-competitors}

Whereas anti-trust policy may solve problems where direct competition, derivative marketers or secondgeneration creators are concerned, not all can rely on the essential facilities doctrine. Arguably one could stretch market definitions so that academic researchers, endusers and consumers are comprised in the equation. This may even work when certain types of data are concerned, such as government information. ${ }^{128}$ However, it is submitted that such information should fall under a limitation or exclusion regime. A recent Directive ${ }^{129}$ on the re-use of public sector information does not contain an obligation to allow re-use of documents, but merely stipulates that when charges are made, the total income from supplying and allowing re-use of documents shall not exceed the cost of collection, production, reproduction and dissemination, together with a reasonable return on investment. ${ }^{130}$ Furthermore, re-use of documents should be open to all potential market participants on a nondiscriminatory basis.

The use of market arguments to support the boundaries of limitations and exceptions to intellectual property rights cannot, however, be sacrosanct. The argument can therefore be made that the ever-strengthened position of the rightholder ought to be checked and balanced by criteria that go beyond an economic calculus. There is a market for ideas and data, but the sole application of market theory to safeguard access has its shortcomings. ${ }^{131}$

A recent Panel Discussion on Intellectual Property and Human Rights ${ }^{132}$ suggests that WIPO is aware of

\footnotetext{
128 See Footnote 5 on the EC Green Paper on Public Sector Information in the Information Society and the ensuing Directive 2003/98/EC.

129 Directive 2003/98/EC Official Journal L345/90 of 31 December 2003.

130 Directive 2003/98/EC, Art. 6.

131 See Barendt (1998, pp. 29-50) arguing at 47, that the alternative lies in the Madisonian model, treating the public not as consumers of information, but as "citizens, entitled to information and a vigorous exchange of ideas and opinion". See also Sunstein (1995, pp. 1759-1765).

132 A Panel Discussion in commemoration of the 50th Anniversary of the Universal Declaration of Human Rights on Intellectual Property and Human Rights organised by the World Intellectual Property Organisation (WIPO) in collaboration with the Office of the United Nations High Commissioner for Human Rights, Geneva, 9 November 1998.
} 
the relationship between intellectual property and human rights. The joint panel discussion organised by WIPO and the Office of the United Nations High Commissioner for Human Rights commemorated the 50th anniversary of the Universal Declaration of Human Rights, and addressed issues such as biodiversity, the protection of traditional knowledge and innovation, the right to culture, health, non-discrimination, and scientific freedom.

During the panel discussions it was emphasised ${ }^{133}$ that the Universal Declaration of Human Rights International Covenant on Economic, Social and Cultural Rights (ICESCR) augments intellectual property law. Articles 27(1) of the Declaration, and 15(1)(b) of the ICESCR guarantee the right to participation in cultural and scientific life. It not only protects the creator to enjoy the fruits of his labour, but also requires the Member States to "facilitate and promote scientific progress and its applications and to do so in a manner that will broadly benefit members of society on an individual as well as a collective level". ${ }^{134}$ The considerations of the ICESCR go well beyond a simple economic calculus. The approach taken with regard to cultural and scientific life is therefore a multifaceted one, describing the right both in terms of access to and engagement in scientific discourse, and the protection of the spiritual and earthly benefits of the creator. Intellectual property law in its narrow sense primarily addresses the rights of the individual creator.

Similarly article 10 of the European Convention on Human Rights lays down the right to freedom of speech as a multifaceted right that not only protects the positive right to expression, but also the right to receive information. Thus far the right to information, its free flow, and academic freedom has had limited application in disputes over the exploitation of intellectual property rights in Europe. ${ }^{135}$ It has been an established case law of the European Court of Human Rights that Member States have a wide margin of appreciation in imposing restrictions on the rights contained in article $10 \mathrm{ECHR}$ in

\footnotetext{
${ }^{133}$ See most notably the document prepared by Dr. A. Chapman - as yet unpublished.

134 Ibid. WIPO-UNHCR/IP/PNL/98/5 Abstract. For the purpose of this paper I will not discuss further issues which have closer links to the Universal Declaration of Human Rights, the draft UN Declaration on the Rights of Indigenous Peoples, the UNESCO Declaration on the Human Genome and Human Rights, the International Covenant on Economic, Social and Cultural Rights, or the UN Convention of Biological Diversity. For these issues I refer to the WIPO-UNHCHR publication.

135 In the US the situation is somewhat different in that courts are willing to intervene on first amendment grounds much more readily. Vide Foerstel (1997) and Loveland (1998).
}

commercial matters. The Court has shown itself particularly sensitive to the enforcement of intellectual property and unfair competition laws. ${ }^{136}$

The case of Hertel v. Switzerland ${ }^{137}$ may change this position, as this is the first case in which the ECHR feels competent to deal with issues of competition law regarding free speech. The European Court of Human Rights struck out the application of the Swiss Unfair Competition $\mathrm{Act}^{138}$ following publication of a scientific article stating that consumption of food prepared in microwave ovens was dangerous to human health. It held that the statements involved were not purely commercial, but formed part of a larger debate taking place in society, reducing the margin of appreciation of the member state. The Court therefore felt free to examine whether the measures restricting the freedom of speech were proportionate to the aims pursued by the Unfair Competition Act. The Hertel decision may signal the involvement of the norms of the ECHR in unfair competition and intellectual property issues by ensuring academic freedom, freedom of speech and freedom of access in the information society. As the judgments of the European Court of Human Rights are directed to the Member States to the Convention, the creation of a direct horizontal right to information derived from jurisprudence may take a long time to develop. The fact that the European Court of Human Rights saw itself fit to decide upon "commercial matters, ... in an area as complex and fluctuating as that of unfair competition" 139 is, however, encouraging for the development of unfair competition law and intellectual property law. The Hertel decision is a positive statement that fundamental rights and freedoms affect commerce. One can envisage, therefore, freedom of speech playing a more prominent role in the balancing of interest. This may be the case in, for example, disparagement of trademarks and imagery, trade libel, and defamation cases, ${ }^{140}$ but also in cases in which the free flow of information is at stake. For the citizens of Europe this means that the right of access to information is not only enforceable against government institutions and the databases generated by or on behalf of governments, but may also be claimed in respect of databases compiled using public sector, or even single

\footnotetext{
136 Markt Intern Verlag GmbH and Klaus Beerman v. Germany, case 3/1988/147/201 (20 November 1989); Jacubowski v. Germany, case 7/1993/402/480 (20 June 1994).

137 European Court of Human Rights, Strasbourg, 25 August 1998, (59/1997/843/1049).

138 Federal Unfair Competition Act of 19 December 1986.

139 Hertel, Footnote 6 and Markt Intern Verlag, Footnote 136.

140 Leigh (1998, pp. 51-68).
} 
source information. ${ }^{141}$ This does not mean that information must always be made available for free, but it will provide a means to assess the equitability of the remuneration that is demanded in return for legitimate user rights to a database.

\section{Conclusion}

The guarantee of a free flow of information is therefore no longer an issue that is limited by the discussion on the scope of IP rights and the traditional exceptions thereto. Whether one uses a proprietary model or a misappropriation model to protect database producers does, however, influence the scope of protection and the way in which limitation and exceptions may be set to fit the circumstances. Moreover, the misappropriation model places database protection in the realm of competition law. This leaves more scope for the assessment of market distortions by anti-trust authorities where the protection of intellectual and industrial creativity is a factor contributing to the abusive behaviour by a rightholder. There is clear scope for courts and policy makers to contribute to the development of an equitable licensing practice in the copyright and database market for the benefit of derivative marketers and second generation creators that are dependent on information.

With the Hertel decision the European Court of Human Rights has claimed a role for itself in commercial matters. In the future the Court may have a more fundamental role to play in the balancing of the interests of individuals and society as a whole in the area of intellectual property. The European Convention itself leaves scope to develop case law and doctrine not only in the area of freedom of expression, but also when it comes to the free flow of information and the participation in academic life. Furthermore, the fundamental decision of the European Court of Human Rights should prompt policy makers to take action to ensure the free flow of information.

\section{References}

Adams, J., 2002. Intellectual Property Quarterly 1, 1.

Akerlof, G.A., 1970. The market for 'Lemons'. Quality uncertainty and the market mechanism. Quarterly Journal of Economics, 488. Arrow, K., 1962. Economic welfare and the allocation of resources for invention. In: The Rate and Direction of Economic Activity Eco-

$\overline{141}$ In this respect one can think of information of fact, such as closing values of indexes generated at the stock exchange. Commonly this information is compiled and disseminated by contractors of the stock exchange authorities. nomic and Social Factors. Princeton University Press, Princeton, NJ.

Band, J., 2005. The Database Debate in the 108th US Congress: The Saga Continues. European Intellectual Property Review 6, 205-212.

Barendt, E., 1998. The first amendment and the media. In: Loveland, I. (Ed.), Importing the First Amendment-Freedom of Speech and Expression in Britain, Europe and the USA. Hart Publishing, Oxford, pp. 29-50.

Barlow, J., 1994. The Economy of Ideas. Wired 2.03 (March), 85.

Beater, A., 1995. Nachahmen im Wettbewerb. Mohr, Tübingen.

Benkler, Y., 2000. Constitutional bounds of database protection: the role of judicial review in the creation and definition of private rights in information. Berkeley Law and Technology Journal 15, 535.

Berger, M., 1997. Die funktionale Konkretisierung von Art. 2 UWG. Schulthess, Zürich.

Besen, S.M., Raskind, L.J., 1991. An Introduction to the Law and Economics of Intellectual Property. Journal of Economic Perspectives, 3.

Calabresi, G., Melamed, A.D., 1972. Property rules, liability rules, and inalienability: one view of the cathedral. Harvard Law Review 85, 1089.

Callmann, R., 1942. He who Reaps where He has not Sown: Unjust Enrichment in the Law of Unfair Competition. Harvard Law Review 55, 595.

Calvet, H., Desurmont, T., 1996. The magill ruling (1): an isolated decision? Revue Internationale du Droit d'Auteur 167, 2.

Coase, R.H., 1960. The problem of social cost. Journal of Law and Economics 3, 1.

Conley, J., Brown, M., Bryan, R., 2000. Database protection in a digital world: why the United States should decline to follow the European model. Information and Communications Technology Law, 27.

Cook, T., 1996. The final version of the EC database directive: a model for the rest of the world? Copyright World 61, 24.

Cornish, W.R., Phillips, J., 1982. The economic function of trademarks: an analysis with special reference to developing countries. International Review of Industrial Property and Copyright Law 13, 41.

Dam, K.W., 1998. Intellectual Property and the Academic Enterprise, John M. Olin, Law \& Economics Working Paper No. 68 (2nd Series). The Law School, The University of Chicago.

De Scitovszky, T., 1941. A note on welfare propositions in economics. Review of Economic Studies, 77.

Demsetz, H., 1982. Barriers to entry. American Economic Review 72, 47.

Denicola, R.C., 1981. Copyright in collections of facts: a theory for the protection of nonfiction literary works. Columbia Law Review $81,516$.

Diamond, S.A., 1980. The public interest and the trademark system. JPOS 62, 528.

Drahos, P., 1999. Intellectual property and human rights. Intellectual Property Quarterly 3, 349-371.

Economides, N.S., 1988. The Economics of Trademarks. Trade Mark Reporter 78, 523.

European Commission Working Paper, 2001. Managing IPR in a knowledge-based economy-bioinformatics and the influence of public policy. Brussels, EUR 20066.

Foerstel, H.N., 1997. Free Expression and Censorship in America-An Encyclopedia. Greenwood Press, Westport/London.

Friedman, D.D., Landes, W.M., Posner, R.A., 1991. Some economics of trade secret law. Journal of Economic Perspectives, 61. 
Gaster, J., 1999. Der Rechtsschutz von Databanken: Kommentar zur Richtlinie 96/9/EG, mit Erläuterungen zur Umsetzung in das Deutsche und Osterreichische Recht. Köln: Heymanns Verlag.

Ginsburg, J., 1992. No "Sweat"? Copyright and Other Protection of Works of Information After Feist v. Rural Telephone. Columbia Law Review 92, 338.

Gordon, W., 1992b. On owning information: intellectual property and the restitutionary impulse. Virginia Law Review 78, 149-281.

Gordon, W.J., 1982. Fair use as market failure: a structural and economic analysis of the betamax case and its predecessors. Columbia Law Review 82, 1600.

Gordon, W.J., 1992a. Asymmetric market failure and prisoners dilemma in intellectual property. University of Dayton Law Review $17,853$.

Green, N., 1993. Intellectual property and the abuse of a dominant position under european union law: existence. exercise and the evaporation of rights. Brooklyn Journal of International Law, 141.

Haines, S., 1994. Copyright takes the dominant position. European Intellectual Property Review 9, 401.

Hardy, T., 1996. The ancient doctrine of trespass to web sites. Journal of Online Law, 7.

Hayek, F.A., 1948. Economics and Knowledge. Individualism and Economic Order. University of Chicago Press, Chicago, IL.

Heald, P., 1991. Federal intellectual property law and the economics of pre-emption. Iowa Law Review 76, 959.

Hicks, J.R., 1939. Foundations of welfare economics. Economic Journal 49, 696.

Hugenholtz, P., 2001. The New Database Right: Early Case Law from Europe. Available at http://www.ivir.nl/publications/ hugenholtz/fordham2001.pdf.

Kaldor, N., 1939. Welfare propositions of economics and interpersonal comparisons of utility. Economic Journal 49, 549.

Karjala, D., 1994. Misappropriation as a third intellectual property paradigm. Columbia Law Review 94, 2594.

Katz, M., Shapiro, C., 1998. Antitrust in Software Markets. Paper presented at the Progress and Freedom Foundation Conference. Competition, Convergence and the Microsoft Monopoly, February 5 .

Kaufer, E., 1989. The Economics of the Piatent System. Harwood Academic Publishers GmbH, Chur.

Kelly, K., 1998. New Rules for the New Economy. Viking Press, New York.

Korah, V., 1994. An Introductory Guide to EC Competition Law and Practice, 5th ed. Sweet \& Maxwell, London.

Korah, V., 2001. The Interface between intellectual property and antitrust: the European experience. Antitrust Law Journal, 801.

Kübler, P., 1999. Rechtsschutz von Databanken (EU-USA-Schweiz). Schulthess Verlag, Zürich.

Laddie, H., 1996. Copyright: over-strength, over-regulated, over-rated? European Intellectual Property Review 5, 260.

Landes, W.M., Posner, R.A., 1987a. Trademark law: an economic perspective. Journal of Law and Economics 30, 265.

Landes, W.M., Posner, R.A., 1987b. The Economic Structure of Tort Law. Harvard University Press, Cambridge, MA.

Landes, W.M., Posner, R.A., 1989. An economic analysis of copyright law. Journal of Economic Studies 18, 325.

Leigh, L., 1998. Of free speech and individual reputation: New York Times v. Sullivan in Canada and Australia. In: Loveland, I. (Ed.), Importing the First Amendment-Freedom of Speech and Expression in Britain, Europe and the USA. Hart Publishing, Oxford, pp. 51-68.
Lloyd, I., 1997. Information Technology Law, 2nd ed. Butterworths, London.

Loveland, I. (Ed.), 1998. Importing the First Amendment-Freedom of Speech and Expression in Britain, Europe and the USA. Hart Publishing, Oxford.

Mackaay, E., 1996. Legal hybrids: beyond property and monopoly? Columbia Law Review 94, 2630.

Mallet-Poujol, N., 1996. The information market: copyright unjustly tormented. Revue Internationale du Droit d'Auteur 167, 92.

Maurer, S., Hugenholtz, P., Onsrud, H., 2001. Europe's Database Experiment. Science 294 (26 Oct.), 789.

Merges, R.P., 1994. Of property rules, coase, and intellectual property. Columbia Law Review 94, 2655.

Miller, C., 1994. Magill: time to abandon the "specific subject-matter" concept. European Intellectual Property Review, 415.

Ohly, A., 1997. Richterrecht und Generalklausel im Recht des unlauteren Wettbewerbs: ein Methodenvergleich des Englischen und des Deutschen Rechts. Köln: Heymann.

Passa, J., 1997. Contrefaçon et Concurrence Déloyale. Paris: Litec.

Pollack, M., 1999. The right to know? Delimiting database protection at the juncture of the commerce clause. the intellectual property clause and the first amendment. Cardozo Arts \& Entertainment Law Journal 17, 47.

Posner, R., 2000. Antitrust in the New Economy. Tech Law Journal 14 September. Available at http://www.techlawjournal. com/atr/20000914posner.asp.

Reichmann, J., 1994. Legal hybrids between the patent and copyright paradigms. Columbia Law Review 94, 2432.

Reichmann, J., Samuelson, P., 1997. Intellectual property rights in data? Vanderbilt Law Review 50, 51.

Samuelson, P., Opsahl, K., 1998. The tensions between intellectual property and contracts in the information age: an american perspective. In: Grosheide, F., Boele-Woelki, K. (Eds.), Molengrafica. Vermande, Lelystad, pp. 163-193.

Sanders, A.K., 1997. Unfair Competition Law-The Protection of Intellectual and Industrial Creativity. Clarendon Press, Oxford.

Sanders, A.K., 1999. Unfair competition law and the European court of human rights, The Case of Hertel v. Switzerland and Beyond. Fordham Intellectual Property Media and Entertainment Law Journal 10,305 .

Sanders, A.K., 2005. Essential facilities and appropriate remuneration of achievements. In: Heath, C., Sanders, A.K. (Eds.), New Frontiers of Intellectual Property Law-IP in Cultural Heritage, Geographical Indications, Enforcement and Overprotection. Hart Publishing, Oxford, pp. 245-265.

Shapiro, C., 1999. Exclusivity in network industries. George Mason Law Review 7, 1.

Stewart T., 1997. Intellectual Capital. Doubleday/Currency.

Sunstein, C., 1757. The first amendment in cyberspace. Yale Law Journal 105.

Tritton, G., 1996. Intellectual Property in Europe. Sweet \& Maxwell, London.

Van Kerckhove, M., 1995. Magill: a refusal to license or a refusal to supply? Copyright World 51 (June/July), 26.

Varian, H., Shapiro, C., 1999. Information Rules-A Strategic Guide to the Network Economy. Harvard Business School Press, Boston, MA.

Warren-Boulton, F., Baseman, K., Woroch G., 1994. The economics of intellectual property protection for software: the proper role for copyright. Paper prepared for the American Council on Interoperable Systems, June, Washington, D.C. 